\title{
IMPACT OF CROSSING MUSCOVY AND SUDANI (EGYPTIAN MUSCOVY) DUCKS ON SOME GROWTH PARAMETERS
}

\section{A. Makram, A. Galal and A.H. El-Attar}

Poultry Production Department, Faculty of Agriculture, Ain Shams University, Cairo, Egypt
Corresponding author: Amer Makram. E-mail: Am150@Favoum.edu.eg

\section{SUMMARY}

The objective of this study is to improve productive performance for Sudani duck by crossing its females with Muscovy males. At 32 wks of age, the Muscovy males (M) were mated with Sudani (S) females. Body weight was recorded according to the marketing age of each strain and the cross, body weight gain; growth rate and feed conversion ratio were weekly calculated. Body measurements were measured from the second week of age. The obtained results showed that the Muscovy and hybrids (MS cross) had significantly the heaviest body weight compared to Sudani ones. A similar trend was found for in the MS cross at all ages when compared to Sudani or Muscovy duck. Concerning feed conversion ratio (4-6 wks), the results showed that there was no significant difference among strains. However, the hybrids (MS cross) had the worst feed conversion ratio compared to their parents from 2-4, 6-8 and 2-8 weeks of age. The MS cross had significantly higher body measurements at 2, 4, 6, 8 and 10 weeks of age compared to their parents. In conclusion, the hybrids (MS cross) recorded the best value (positive heterosis) for body weight at all ages With respect to growth rate, the heterosis had positive effect at all ages except from 4-5 and 9-10 weeks of age.

\section{Keywords: Growth parameters, Body measurements, Sudani, Muscovy duck, MS Cross, Heterosis}

\section{INTRODUCTION}

Duck is a major producer of protein of high quality for human nutrition in the form of meat, because of their high nutritive value especially their contents of essential amino acids. The demand on animal protein is rising worldwide, however the supply is not sufficient to cover the demand (Mossad, 2006). Many duck breeds are known for fast growth and heavy body weight during the shortest possible period of time. The crossbred between the Muscovy drakes (Cairina moschata) and the Pekin ducks (Anas platyrhynchos) is the mule ducks (Anas sterilis) has been popular for many years ago and are used for meat and liver production (Akinlade and Sonaiya, 1994; Adenowo et al., 1999 and Adeyeye et al., 2012). Sudani ducks are considered a local breed and more favorable to the Egyptian consumer and more heat tolerant as compared to Muscovy duck (foreign breed). Phenotypic comparison based on morphological characters can provide to some extent a reasonable representation of genetic differentiation among populations (El-Soukkary et al., 2005 and Galal et al., 2011). This genetic variation in the duck populations is essential for the development of appropriate breeding goals and programmers for each agro-ecological zone (Bulgarella et al., 2007). This experiment was designed to evaluate some growth parameters among Muscovy, Sudani and their cross.

\section{MATERIALS AND METHODS}

This experiment was carried out at a private farm in Fayoum Governorate. A total number of 275 (150 Sudani and 125 Muscovy) one day old un-sexed ducks were used. They were reared under similar environmental, managerial and hygienic conditions from one day old to the end of the experiment. The feed and water were offered ad libtium. They were fed a diet containing $22 \%$ protein (P) and $2900 \mathrm{Kcal}$ for Sudani, Muscovy and the cross (0-4 wk), $20 \% \mathrm{P}$ and 2900 Kcal for Sudani, Muscovy and their cross (four wks - marketing age). The high and low ambient temperatures and relative humidity were recorded during the experimental period (Figure 1). At 32 wk of age, 7 Muscovy males (M) were allowed for natural mating with 28 Sudani (S) female (Each male is mated with four females). The total number offspring produced from this mating were 115 ducklings.

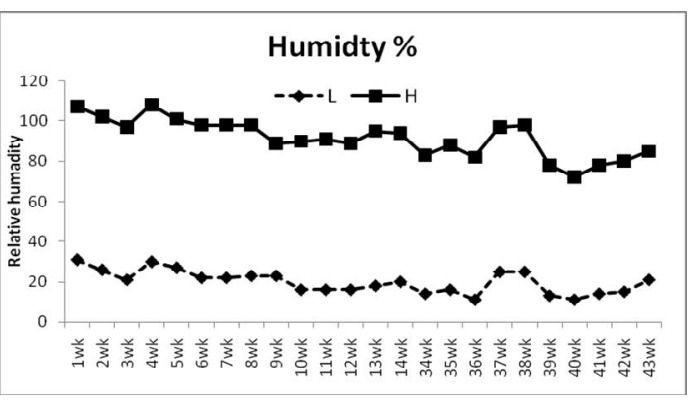

Fig. 1. Ambient temperature $\left({ }^{\circ} \mathrm{c}\right)$ and humidity (\%) recorded during the experimental period 


\section{Measurements and observations:}

Body weight:

All ducks were weighed at marketing age 10, 12, 14 for the hybrids (MS cross), Muscovy and Sudani ducks, respectively.

\section{Growth rate:}

The growth rate was calculated as the following equation (Brody, 1945):

$$
\text { Growth rate }(\mathrm{GR})=\frac{\mathrm{W} 2-\mathrm{W} 1}{0.5(\mathrm{~W} 2+\mathrm{W} 1)} \times 100
$$

Where: $\mathrm{W} 1=$ initial weight, $\mathrm{W} 2=$ second weight.

\section{Feed consumption and feed conversion ratio:}

Feed consumption and feed conversion ratio were weekly calculated for birds representing all duck strains from day-old to marketing age. Ten birds from each strain were randomly chosen and divided into 5 replicates, each replicate containing two ducks (as an experimental unit). Feed consumption was weekly measured and for the whole experimental period. Feed conversion rate (FCR) was measured as follows:

Feed conversion ratio $=$ F.C. $/ \Delta w t$

Feed consumption (F.C.) $=$ feed consumed during one week

Weight gain $(\Delta w t)=$ weight gain in grams within one week

\section{Body Measurements:}

These measurements included shank length (SL) from the top of the hock joint to the foot pad and keel length (KL) the keel bone length supporting the breast fillet were measured with a digital caliper, breast circumference (BC) taken under the wings at the edge of the sternum and body length (BL) longitudinal body beginning from beak to termination bird foot were measured by measuring tape.

\section{Heterosis:}

The crossbred effect (Hybrid vigor) or heterosis (expressed as a percent) was calculated as follows:

$$
\text { Heterosis } \%=\frac{\text { Mean cross breed (XC)-Mean pure breed (XP) }}{\text { Mean pure breed (XP) }} \text { X100 }
$$

Statistical analysis:

Data were subjected to an one -way analyses of variance with cross effect using the General Linear Model (GLM) procedure of SAS User's Guide (2001).

\section{RESULTS AND DISCUSSION}

\section{Body weight and Body weight gain:}

Body weight and body weight gain of Sudani, Muscovy and their cross are presented in Tables 1 and 2. The results showed that the MS cross had significantly the lowest body weight compared to their parents at one day old. Such result may be attributed to the small hatching eggs produced by Sudani ducks. The body weight of a newly-hatched bird may be also considerably affected by the genotype of parents (Wittmann, 1997). In the first week of age, Muscovy and MS cross had significantly the heaviest body weight compared to Sudani duck. A similar trend was found for in the MS cross at all ages when compared to Sudani or Muscovy duck. Pingel and Jeroch (1972) reported that body weight of crossbred between Muscovy and Pekin ducks at eight weeks of age was higher than those of the parents pure breeds. Concerning body weight gain the MS cross had a significantly the heaviest body weight gain at all ages compared to Muscovy and Sudani one, except at 5-6 weeks of age. Muscovy ducks had significantly higher body weight gain compared to either Sudani or MS cross. The body gain of hybrid (MS cross) during 10 weeks was exceeded their parental strain by about 12.7 and 42.2 $\%$ for Muscovy and Sudani ducks, respectively.

Table 1. Body weight of parent's ducks and MS cross (Means \pm SE) at marketing age

\begin{tabular}{ccccc}
\hline $\begin{array}{c}\text { Age } \\
\text { (Week) }\end{array}$ & \multicolumn{2}{c}{ Strain } & MS cross & Level of significant \\
\cline { 2 - 3 } & Muscovy & Sudani & & \\
\hline 0 & $51.73^{\mathbf{a}} \pm 1.51$ & $44.30^{\mathbf{b}} \pm 0.36$ & $39.63^{\mathbf{c}} \pm 1.59$ & 0.0001 \\
1 & $87.29^{\mathbf{a}} \pm 2.15$ & $71.07^{\mathbf{b}} \pm 0.99$ & $89.00^{\mathbf{a}} \pm 5.05$ & 0.0001 \\
2 & $173.85^{\mathbf{b}} \pm 4.52$ & $140.92^{\mathbf{c}} \pm 2.57$ & $198.79^{\mathbf{a}} \pm 14.67$ & 0.0001 \\
3 & $314.71^{\mathbf{b}} \pm 9.55$ & $291.34^{\mathbf{b}} 6.28$ & $402.79^{\mathbf{a}} \pm 22.67$ & 0.0001 \\
4 & $583.12^{\mathbf{b}} 15.31$ & $535.10^{\mathbf{b}} \pm 11.06$ & $689.58^{\mathbf{a}} \pm 32.50$ & 0.0001 \\
5 & $975.47^{\mathbf{a}} 33.99$ & $807.67^{\mathbf{b}} 16.69$ & $1002.86^{\mathbf{a}} 2.10$ & 0.0001 \\
6 & $1072.96^{\mathbf{b}} 2.44$ & $961.66^{\mathbf{b}} 25.18$ & $1227.00^{\mathbf{a}} 3.29$ & 0.0001 \\
7 & $1378.57^{\mathbf{b}} 32.43$ & $1191.18^{\mathbf{c}} 33.17$ & $1575.56^{\mathbf{a}} \pm 67.04$ & 0.0001 \\
8 & $1693.10^{\mathbf{b}} 47.08$ & $1491.21^{\mathbf{b}} 43.00$ & $1873.94^{\mathbf{a}} \pm 120.09$ & 0.0002 \\
9 & $2033.08^{\mathbf{a}} \pm 60.77$ & $1648.54^{\mathrm{a}} 52.57$ & $2242.47^{\mathbf{a}} 120.09$ & 0.0001 \\
10 & $2359.12^{\mathbf{b}} \pm 92.01$ & $1884.13^{\mathbf{c}} 65.15$ & $2668.16^{\mathbf{a}} 172.89$ & 0.0001 \\
\hline
\end{tabular}

$\mathrm{a}, \mathrm{b}$ and $\mathrm{c}$ Means within the same row with different letters are significantly different. 
Table 2. Body weight gain of parent's ducks and MS cross (Means $\pm \mathrm{SE}$ ) at marketing age

\begin{tabular}{ccccc}
\hline Age (Week) & \multicolumn{2}{c}{ Strain } & MS cross & Level of significant \\
\cline { 2 - 4 } & Muscovy & Sudani & $49.73^{\mathbf{a}} 2.53$ & 0.0001 \\
$0-1$ & $35.68^{\mathbf{b}} \pm 1.11$ & $26.72^{\mathbf{c}} \pm 0.67$ & $102.39^{\mathrm{a}} 5.83$ & 0.0001 \\
$1-2$ & $68.07^{\mathbf{b}} \pm 2.63$ & $68.63^{\mathbf{b}} \pm 1.62$ & $207.03^{\mathrm{a}} 5.32$ & 0.0001 \\
$2-3$ & $151.54^{\mathbf{b}} \pm 5.84$ & $144.54^{\mathbf{b}} \pm 3.57$ & $286.14^{\mathrm{a}} \pm 7.34$ & 0.0001 \\
$3-4$ & $223.01^{\mathbf{b}} \pm 6.26$ & $239.85^{\mathbf{b}} \pm 5.16$ & $369.34^{\mathrm{a}} \pm 3.95$ & 0.0001 \\
$4-5$ & $328.29^{\mathbf{a}} 20.43$ & $274.60^{\mathbf{b}} \pm 5.56$ & $219.23^{\mathbf{b}} \pm 7.81$ & 0.0001 \\
$5-6$ & $250.20^{\mathbf{a}} 17.36$ & $152.59^{\mathbf{c}} 10.70$ & $351.11^{\mathrm{a}} \pm 11.43$ & 0.0001 \\
$6-7$ & $241.07^{\mathbf{b}} \pm 8.80$ & $173.55^{\mathbf{c}} 13.29$ & $301.12^{\mathrm{a}} \pm 47.27$ & 0.0001 \\
$7-8$ & $396.51^{\mathbf{a}} \pm 13.11$ & $253.83^{\mathbf{b}} \pm 9.62$ & $368.33 \mathrm{~b}^{\mathrm{a}} \pm 10.30$ & 0.0001 \\
$8-9$ & $342.04^{\mathrm{a}} \pm 26.10$ & $159.85^{\mathrm{b}} \pm 20.75$ & $427.19^{\mathrm{a}} \pm 39.89$ & 0.0001 \\
$9-10$ & $329.42^{\mathrm{b}} \pm 17.01$ & $235.92^{\mathrm{b}} \pm 20.88$ & $2628.43^{\mathrm{a}} \pm 117.58$ & 0.0001 \\
$0-10$ & $2330.76^{\mathrm{b}} 84.22$ & $1848.26^{\mathbf{c}} \pm 95.37$ &
\end{tabular}

a, b and c Means within the same row with different letters are significantly different.

\section{Growth rate:}

The growth rate of Sudani, Muscovy and their cross are presented in Table (3) and Figure (2). Generally, the MS cross had significantly higher growth rate from 0 - 5 wk of age compared to their parents. While, from 3 to 4 weeks of age, Sudani strain had significantly higher growth rate compared to Muscovy and MS cross. From to 7 weeks of age, the Muscovy recorded significantly the highest growth rate compared to MS cross one. However, the Sudani duck recorded the lowest value. From 9 to 10 weeks of age, Muscovy duck had significantly higher growth rate compared to Sudani and MS cross. The growth rate was affected by genetic, environment and interaction between them (Kor et al., 2006). Body growth in livestock may be evaluated with body components such as live weight and body measurements (Wolanski et al., 2006; Saatci and Tilki, 2007). A crossbreeding could lead to production of birds that will be better in growth rate, efficiency of feed conversion and reproductive traits without sacrificing adaptation to the local environment, thereby resulting in reduced cost of production (Adebambo et al., 2011). The outcome of crossbreeding is due to the phenomenon of heterosis, which is expressed in the performance of the hybrids. Since heterosis is almost exclusively the aggregate of all single locus dominance effects, and as these are usually positive or beneficial, heterosis can be expected to be usually in the favorable direction (Kitalyi, 1998 and Khawaja et al., 2012).

Table 3. A Growth rate of parent's ducks and MS cross (Means \pm SE) at marketing age

\begin{tabular}{|c|c|c|c|c|c|}
\hline \multirow[t]{2}{*}{ Age (Week) } & \multicolumn{3}{|c|}{ Strains } & \multirow[t]{2}{*}{ MS cross } & \multirow[t]{2}{*}{ Level of significant } \\
\hline & Musc & ovy & Sudani & & \\
\hline $0-1 w k$ & $50.59^{b}$ & \pm 0.58 & $45.33^{\mathbf{b}} \pm 0.77$ & $76.96^{\mathrm{a}} \pm 1.31$ & 0.0001 \\
\hline 1-2 wk & $53.86^{\mathrm{c}}$ & \pm 1.16 & $63.74^{\mathrm{b}} \pm 0.54$ & $71.81^{\mathrm{a}} \pm 1.33$ & 0.0001 \\
\hline 2-3 wk & $62.81^{b}$ & \pm 0.75 & $65.27^{\mathbf{b}} \pm 0.325$ & $69.49^{\mathrm{a}} \pm 1.35$ & 0.05 \\
\hline 3-4 wk & $47.14^{b}$ & \pm 0.35 & $57.90^{\mathrm{a}} \pm 0.27$ & $52.93^{\mathrm{b}} \pm 0.81$ & 0.0001 \\
\hline 4-5 wk & $41.15^{\mathbf{b}}$ & \pm 0.72 & $41.09^{\mathbf{b}} \pm 0.20$ & $46.25^{\mathrm{a}} \pm 1.66$ & 0.05 \\
\hline 5-6 wk & $25.11^{\mathrm{a}}$ & \pm 2.66 & $11.26^{\mathbf{c}} \pm 0.90$ & $19.65^{b} \pm 0.47$ & 0.0001 \\
\hline 6-7 wk & $20.23^{\mathrm{a}}$ & \pm 0.46 & $14.79^{\mathbf{b}} \pm 0.418$ & $17.09^{\mathrm{b}} \pm 1.01$ & 0.0001 \\
\hline 7-8 wk & 17.99 & \pm 0.60 & $15.43 \pm 0.81$ & $16.30 \pm 1.95$ & NS \\
\hline 8-9wk & $12.06^{\mathrm{b}}$ & \pm 0.76 & $19.49^{\mathrm{a}} \pm 0.77$ & $17.93^{\mathrm{a}} \pm 1.00$ & 0.0001 \\
\hline 9-10wk & $36.20^{\mathrm{a}}$ & \pm 0.57 & $19.17^{\mathbf{b}} \pm 0.88$ & $13.54^{\mathrm{c}} \pm 0.92$ & 0.0001 \\
\hline
\end{tabular}

a, b and c Means within the same row with different letters are significantly different, NS = Non-significant.

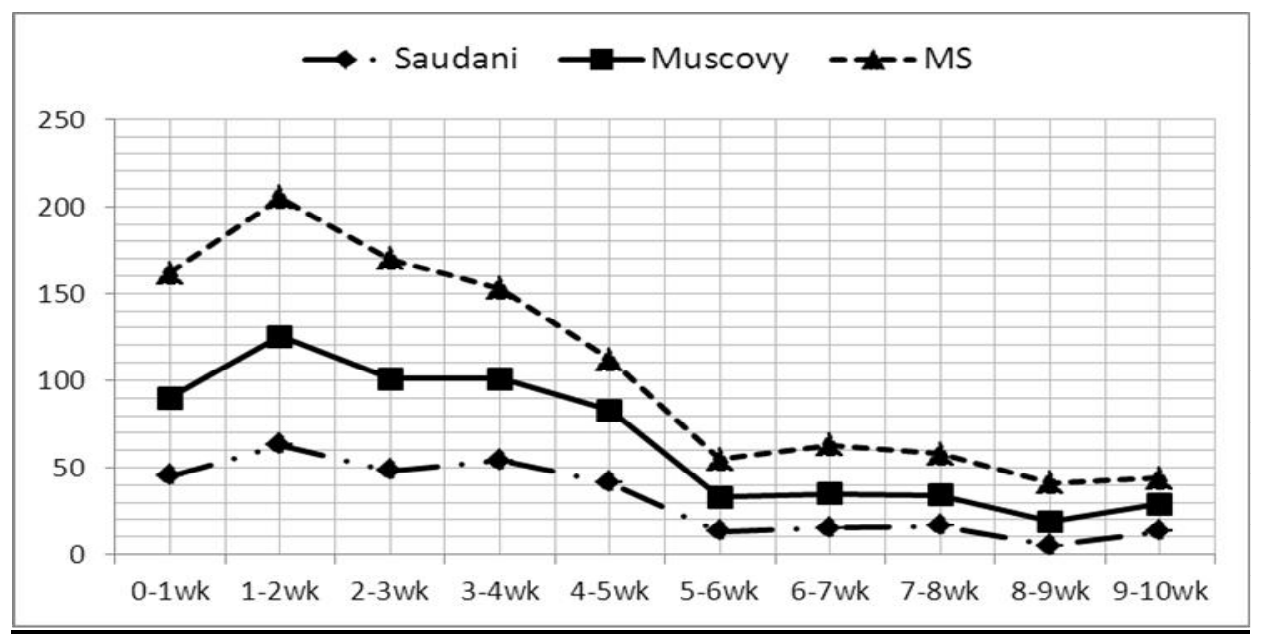

Fig. 2: Growth rate of Sudani, Muscovy ducks and their cross from 0-10wk 


\section{Feed consumption and feed conversion ratio:}

The feed consumption and feed conversion ratio of MS cross and their parents are presented in Table (4). With respect to feed consumption, MS cross had consumed significantly more feed at all ages compared to their parents. Concerning to body weight gain, the present results indicated that the MS cross had significantly heavier body weight gain at 6 8 weeks of age compared to their parents. The opposite trend was noticed from 8-10 and 2-10 weeks of age. Concerning feed conversion ratio (4-6 wks), the result indicted that there was no significant difference among ducks. Retailleau, (1999) reported that the feed conversion ratio was 2.5 and 2.9 for Pekin and Muscovy duck males measured between 0 and 49 days of age and between 0 and 84 days of age respectively. Mule ducks had intermediate feed efficiency when compared to their parents (Guy et al., 1999; Baeza, et al., 2005).

Table 4. Feed consumption and feed conversion ratio of Muscovy Sudani ducks and MS cross (Means \pm SE) at marketing age

\begin{tabular}{|c|c|c|c|c|}
\hline \multirow[b]{2}{*}{ Period (Week) } & \multicolumn{2}{|l|}{ Strains } & \multirow[t]{2}{*}{ MS cross } & \multirow[b]{2}{*}{ Level of Significant } \\
\hline & Muscovy & Sudani & & \\
\hline \multicolumn{5}{|c|}{ Feed Consumption (g) } \\
\hline $2-4$ & $1036.00^{\mathbf{b}} \pm 76.33$ & $909.80^{\mathbf{b}} \pm 82.08$ & $1290.00^{\mathrm{a}} \pm 36.41$ & 0.0001 \\
\hline 4-6 & $2002.40^{\mathbf{b}} \pm 110.86$ & $1506.20^{\mathbf{c}} \pm 131.61$ & $1980.00^{\mathrm{a}} \pm 58.06$ & 0.0002 \\
\hline 6-8 & $2224.75^{\mathbf{b}} \pm 18.85$ & $1679.20^{\mathbf{b}} \pm 89.71$ & $2826.20^{\mathrm{a}} \pm 12.10$ & 0.0001 \\
\hline $8-10$ & $2489.34^{\mathrm{a}} \pm 77.06$ & $1986.5^{\mathrm{b}} \pm 57.44$ & $2521.21^{\mathrm{a}} \pm 96.71$ & 0.0008 \\
\hline $2-10$ & $7744.63^{\mathrm{b}} \pm 79.56$ & $6081.57^{c} \pm 159.11$ & $8618.40^{\mathrm{a}} \pm 101.34$ & 0.0001 \\
\hline \multicolumn{5}{|c|}{ Body weight gain $(g)$} \\
\hline $2-4$ & $482.80 \pm 42.88$ & $401.20 \pm 30.64$ & $472.00 \pm 24.59$ & N.S \\
\hline 4-6 & $604.4 \pm 31.73$ & $620.80 \pm 56.87$ & $675.20 \pm 37.74$ & N.S \\
\hline $6-8$ & $726.20^{\mathbf{a b}} \pm 87.99$ & $506.40^{\mathbf{b}} \pm 35.82$ & $720.40^{\mathrm{a}} \pm 21.41$ & 0.009 \\
\hline 8-10 & $857.5^{\mathrm{a}} \pm 83.49$ & $816^{\mathrm{ab}} \pm 76.84$ & $618.20^{\mathrm{b}} \pm 21.70$ & 0.05 \\
\hline $2-10$ & $2731.96^{\mathrm{a}} \pm 53.8$ & $2106.76^{c} \pm 59.63$ & $2485.8^{\mathrm{b}} \pm 61.17$ & 0.0001 \\
\hline \multicolumn{5}{|c|}{ Feed Conversion Ratio } \\
\hline $2-4$ & $2.16^{\mathrm{b}} \pm 0.10$ & $2.28^{\mathrm{b}} \pm 0.16$ & $2.85^{\mathrm{a}} \pm 0.16$ & 0.05 \\
\hline 4-6 & $3.32 \pm 0.13$ & $2.50 \pm 0.28$ & $2.91 \pm 0.24$ & N.S \\
\hline 6-8 & $2.84^{\mathrm{ab}} \pm 0.15$ & $3.35^{\mathrm{b}} \pm 0.17$ & $3.85^{\mathrm{a}} \pm 0.09$ & 0.05 \\
\hline $8-10$ & $2.98^{\mathrm{b}} \pm 0.28$ & $2.55^{\mathrm{b}} \pm 0.31$ & $4.00^{\mathrm{a}} \pm 0.17$ & 0.003 \\
\hline $2-10$ & $2.84^{\mathrm{b}} \pm 0.03$ & $2.9^{\mathrm{b}} \pm 0.13$ & $3.48^{\mathrm{a}} \pm 0.09$ & 0.001 \\
\hline
\end{tabular}

\section{Body measurements:}

The shank length, keel length, body circumference and body length of MS cross and their parents are presented in Table (5). The MS cross recorded high value for shank length at 2, 4 and 6 weeks of age compared to their parents. There was no significant difference between Sudani and Muscovy duck and their cross for shank length measured at 8 and 10 wks. Concerning keel length, body circumference and body length, it can notice that the MS cross had significantly higher body measurements at 2, 4, 6, 8 and 10 weeks of age compared to Sudani and Muscovy ducks.

\section{Heterosis:}

Heterosis is a genotypic result of specific combining ability of crossbred strains of fowls. It is usually presented as the domination of the average performance of the first generation hybrids over the average performance of their parents. Effect of heterosis on body weight and growth rate of MS cross is summarized in Table (6). The present results showed negative heterosis at one day old of body weight; however, there was positive heterosis at all ages except at marketing age there was negative value only for MS cross. With respect to growth rate, the heterosis had a positive effect at all ages except from 4-5 and 9-10 weeks of age. 
Table 5. Body measurements of Muscovy Sudani ducks and MS cross (Means \pm SE) at marketing age (offspring flock)

\begin{tabular}{|c|c|c|c|c|c|}
\hline \multicolumn{6}{|c|}{ Shank Length (ShL) (cm) } \\
\hline Strains & $2 w k$ & $4 w k$ & 6wk & 8wk & 10 wk \\
\hline Muscovy & $2.13^{b} \pm 0.04$ & $4.65^{b} \pm 0.07$ & $6.09^{b} \pm 0.14$ & $6.49 \pm 0.19$ & $7.36 \pm 0.31$ \\
\hline Sudani & $3.32^{\mathbf{b}} \pm 0.04$ & & $5.44^{\mathbf{c}_{ \pm}} \pm 0.11$ & $6.60 \pm 0.15$ & $6.66 \pm 0.22$ \\
\hline MS & $3.54^{\mathrm{a}} \pm 0.07$ & $5.75^{\mathrm{a}} \pm 0.15$ & $6.96^{\mathrm{a}} \pm 0.21$ & $7.11 \pm 0.30$ & $7.26 \pm 0.28$ \\
\hline Level of Significant & 0.0001 & 0.0001 & 0.0001 & NS & NS \\
\hline \multicolumn{6}{|c|}{ Keel Length $(\mathrm{KL})(\mathrm{cm})$} \\
\hline Strains & 2wk & $4 \mathrm{wk}$ & 6wk & $8 w k$ & 10 wk \\
\hline Muscovy & $1.61^{b} \pm 0.06$ & $4.66^{b} \pm 0.13$ & $7.39^{\mathrm{a}} \pm 0.20$ & $8.90^{\mathbf{b}} \pm 0.32$ & $11.46 \pm 0.33$ \\
\hline Sudani & $3.36^{\mathrm{a}} \pm 0.04$ & $3.75^{c} \pm 0.12$ & $6.16^{\mathbf{b}} \pm 0.13$ & $8.45^{\mathbf{b}} \pm 0.21$ & $10.26 \pm 0.44$ \\
\hline MS & $3.36^{\mathrm{a}} \pm 0.05$ & $6.29^{\mathrm{a}} \pm 0.23$ & $7.29^{\mathrm{a}} \pm 0.29$ & $10.56^{\mathrm{a}} \pm 0.22$ & $10.79 \pm 0.33$ \\
\hline Level of Significant & 0.0001 & 0.0001 & 0.0001 & 0.0001 & NS \\
\hline \multicolumn{6}{|c|}{ Body circumference $(\mathrm{BC})(\mathrm{cm})$} \\
\hline Strains & $2 \mathbf{w k}$ & $4 \mathrm{wk}$ & $6 \mathrm{wk}$ & 8wk & 10 wk \\
\hline Muscovy & $12.88^{b} \pm 0.15$ & $21.52^{b} \pm 0.30$ & $27.33^{b} \pm 0.41$ & $33.43^{b} \pm 0.45$ & $38.62^{\mathrm{b}} \pm 0.50$ \\
\hline Sudani & $11.80^{\mathbf{b}} \pm 0.16$ & $17.95^{\mathbf{c}} \pm 0.23$ & $25.38^{\mathbf{c}} \pm 0.48$ & $30.10^{\mathbf{c}} \pm 0.60$ & $34.44^{\mathrm{c}} \pm 0.81$ \\
\hline MS & $21.22^{\mathrm{a}} \pm 0.47$ & $30.89^{\mathrm{a}} \pm 1.23$ & $35.88^{\mathrm{a}} \pm 1.19$ & $43.25^{\mathrm{a}} \pm 1.66$ & $45.00^{\mathrm{a}} \pm 1.19$ \\
\hline Level of Significant & 0.0001 & 0.0001 & 0.0001 & 0.0001 & 0.0001 \\
\hline \multicolumn{6}{|c|}{ Body Length (BL) (cm) } \\
\hline Strains & 2wk & $4 \mathrm{wk}$ & $6 \mathrm{wk}$ & 8wk & 10 wk \\
\hline Muscovy & $28.55^{b} \pm 0.42$ & $48.10^{b} \pm 0.50$ & $57.60^{b} \pm 0.89$ & $65.10^{b} \pm 0.13$ & $75.11^{\mathrm{a}} \pm 0.66$ \\
\hline Sudani & $26.51^{c} \pm 0.22$ & $42.03^{c} \pm 0.45$ & $56.78^{\mathbf{b}} \pm 0.67$ & $64.83^{b} \pm 0.95$ & $67.48^{\mathrm{b}} \pm 1.75$ \\
\hline MS & $39.65^{\mathrm{a}} \pm 0.41$ & $53.90^{\mathrm{a}} \pm 0.66$ & $67.10^{\mathrm{a}} \pm 0.86$ & $74.50^{\mathrm{a}} \pm 2.48$ & $78.13^{\mathrm{a}} \pm 3.17$ \\
\hline Level of Significant & 0.0001 & 0.0001 & 0.0001 & $\mathbf{0 . 0 0 0 7}$ & 0.0005 \\
\hline
\end{tabular}

${ }^{a}, \mathrm{~b}$ and $\mathrm{c}$ Means within the same row with different letters are significantly different.

$\mathrm{NS}=$ Non-significant

Table 6. Effect of heterosis (\%) on body weight and growth rate for MS cross

\begin{tabular}{|c|c|c|c|}
\hline \multicolumn{4}{|c|}{ MS cross } \\
\hline Age wk & Body Weight (g) & Age (wk) & Growth rate \\
\hline 0 & -32.84 & $0-1$ & 43.93 \\
\hline $1 w k$ & 7.57 & $1-2$ & 8.86 \\
\hline $2 w k$ & 28.60 & $2-3$ & 8.77 \\
\hline $3 w k$ & 15.12 & $3-4$ & 1.62 \\
\hline $4 w k$ & 15.85 & $4-5$ & -29.84 \\
\hline $5 w k$ & 7.62 & $5-6$ & 4.45 \\
\hline $6 w k$ & 8.49 & $6-7$ & 46.55 \\
\hline $7 \mathrm{WK}$ & 6.30 & $7-8$ & 24.70 \\
\hline 8WK & 10.33 & 8-9 & 13.66 \\
\hline 9wk & 21.82 & $9-10$ & -51.00 \\
\hline 10 wk & 25.76 & & \\
\hline
\end{tabular}

\section{REFERENCES}

Adebambo, A.O., C.O.N. Ikeobi, M.O. Ozoje, O.O. Oduguwa, O.A. Adebambo, 2011. Combining abilities of growth traitsamong pure and crossbred meat type chickens. Arch. Zootec. 60:953-963.

Adenowo, J. A., F. A. Awe, O. A. Adebambo and C. N Ikeobi, 1999. Book Proceedings: 26th of Annual NSAP Conference 21-25 March, University of Ilorin, and Ilorin: 278-280.

Adeyeye, E. I., W. B. Adebayo and O. O. Ayejuyo, 2012. The amino acid profiles of the yolk and albumen of domestic duck (Anas platyrhynchos) egg consumed in Nigeria. Elixir Food Science 52: 11350-11355.
Akinlade, O.R. and E.B. Sonaiya, 1994. A paper, 19th Annual Conference of NSAP, University of Benin.

Baeza E, N. Rideau, P. Chartrin, S. Davail, R. HooParis, J. Mourot, G. Guy, M.D. Bernadet and D. Hermier, 2005. Canards de Barbarie, Pékin et leurs croisements: aptitude à l'engraissement. Prod Anim. 18: 131-141.

Brody, S., 1945, Bioenergetics and Growth. New York: Reinhold Publishing Co.

Bulgarella, M., R. E. Wilson, C. Kopuchian, T. H. Valqui and K. G. McCracken, 2007. Elevational variation in body size of crested ducks (Lophonetta specularioides) from the central high Andes, Mendoza and Patagonia. Ornitologia Neotropical, 18: 587- 602. 
El-Soukkary, F. A., H. M. Mohamed, A. A. Dawood and S. Y. Abd-El Sayed, 2005. Physico-chemical, microbiological and lipid characteristics of duck meat. Minufiya J. Agric. Res., 30: 527-548.

Galal, A., W.A.H. Ali, A.M.H. Ahmed and Kh. A.A. Ali, 2011. Performance and carcass characteristics of Domyati, Muscovy, Peking and Sudani duck breed. Egypt. J. Anim. 48(2):191202.

Guy, G., D. Hermier, S. Davail, M. Bely, J.P. Andre and R. Hoo-Paris. 1999. Meat production and force-feeding ability of different type of ducks. Proceedings of the 1st World Waterfowl Conference, Taichung, Taiwan, 462-468.

Khawaja, T., S. Khan, N. Mukhtar \& A. Parveen 2012.Comparative study of growth performance, meat quality and haematological parameters of Fayoumi, Rhode Island Red and their reciprocal crossbred chickens, Italian Journal of Animal Science, 11:2, e39, DOI: 10.4081/ijas.2012.e39.

Kitalyi, A.J., 1998. Village chickens productionsystems in rural Africa: household food security and gender issues. FAO Animal Production and Health Paper 142, Fao Publ., Roma, Italy.

Kor, A., E. Baspinar, S. Karaca, and S. Keskin, 2006. The determination of growth in Akkeci (White goat) female kids by various growth models. Czech. J. Anim. Sci., 51: 110-116.

Mossad, F. A. T, 2006. Effect of crossing different strains of duck on some productive traits. M.Sc. Faculty of Agric. Al- Azhar. Univ, Egypt.
Pingel, H. and H. Jeroch, 1972. Investigations on fattening and carcass performance as well as meat quality of Muscovy drakes $\times$ Pekin duck crossbreds. Anim. Breed. Abst. Vol. 40: No. 3694.

Retailleau B, 1999. Comparison of the growth and body composition of 3 types of ducks: Pekin, Muscovy and mule. Proceedings of the 1st World Conference on Waterfowl, Taichung, Taiwan, 597-602.

Saatci, M. and M. Tilki, 2007. Zoometrical body measurements and their relation with live weight in native Turkish geese. Turk. J. Vet. Anim. Sci. 31: 47-53.

SAS Institute, 2001. SAS/STAT User's Guide Version 8.2 ed: Statistics. SAS Institute Inc., Cary, NC.

Wittmann, M, 1997. Influence of age, sex and genotype on fattening performance, slaughtering results, and meat quality of geese on intensive feeding. Proc. 11th European Symp on Waterfowl, Nantes, France, 561-568.

Wolanski, N. J., R.A. Renema, F. E. Robinson, V. L. Carney, and B. I. Fanchert, 2006. Relationship between chick conformation and quality measures with early growth traits in males of eight selected pure or commercial broiler breeder strains. Poult. Sci.85: 1490-1497.

\footnotetext{
تأثير الخلط بين البط المسكوفي واليط السوداني (المسكوفي المصري) علي بعض مقاييس النمو

عامر مكرم علي، أحمد جلال السبد، أحمد حاتم إبراهيم العطار

قسم إتتاج الدواجن، كلية الزراعة، جامعة عين شسس، القاهرة، مصر

الهدف من هذه الدر اسة تحسين الأداء الانتاجي للبط السوداني عن طريق خلط اناثه مع ذكور البط المسكوفي. عند عمر بـ أسبو أسبوع تم تلقيح

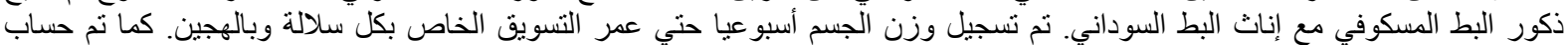

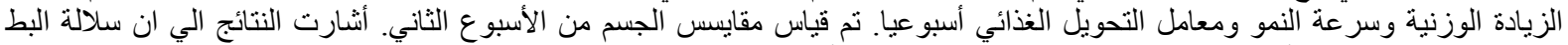

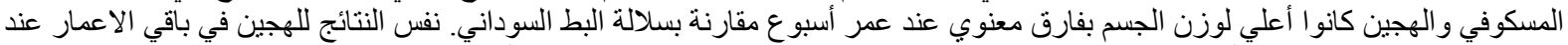

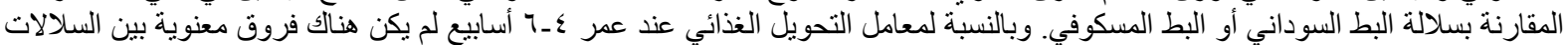

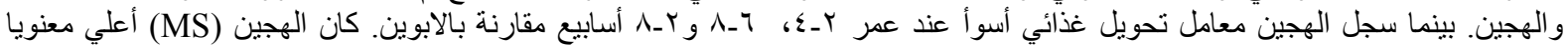

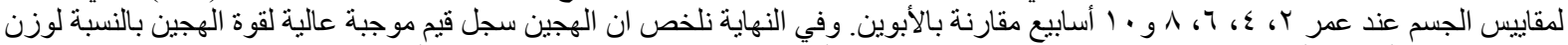

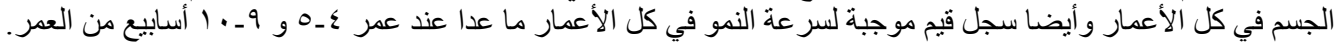

